\title{
The Assisted
}

\section{Human}

\section{Reproduction Act Reference and the Thin Line Between}

Health and Crime

\section{Ubaka Ogbogu*}

\section{When should health be treated as a subject of criminal law?}

With respect to health, the Constitution Act, $1867^{1}$ does not specifically assign legislative authority to any level of government. ${ }^{2}$ As a result, Parliament and provincial legislatures can enact laws relating to health. ${ }^{3}$ This inevitably leads to disputes between both levels of government over who has the authority to enact legislation to deal with whatever aspect of health is in question. However, it is now fairly well established that Parliament can regulate health using its criminal law power, among others, and that the provinces can do the same under various heads of provincial powers. ${ }^{4}$ The courts have also laid down a number of guiding principles to help delineate the legislative space occupied by each level of government in health and other subjects of shared jurisdiction. ${ }^{5}$ Still, controversy remains, as was the case in the Assisted Human Reproduction Act reference, ${ }^{6}$ which considered whether Parliament acted within its authority in using the criminal law power to enact provisions governing aspects of assisted human reproduction and related research.

With respect to criminal law, since the Margarine Reference, ${ }^{7}$ it has become trite to say that to be constitutionally valid, criminal law must possess three elements: (1) a prohibition, (2) backed by a penalty, (3) which advances a valid criminal law public purpose such as public peace, safety, order, security, morality, health, environmental protection or "some similar purpose." 8 The former two are often described as the formal components of criminal law, and the latter as the substantive component. ${ }^{9}$ In the context of health matters, the prevailing judicial opinion is that the substantive component must address a legitimate public health evil. ${ }^{10}$ To be constitutionally valid, therefore, criminal laws that purport to regulate health must be supported by the valid criminal law public purpose of suppressing a legitimate public health evil.

In AHRA Reference, ${ }^{11}$ two panels of Supreme Court justices offered divergent opinions on the nature and scope of the substantive component of criminal laws directed at health matters. Four justices, led by Lebel and Deschamps JJ, ruled that that to be constitutionally valid, the public health evil that Parliament is seeking to suppress must have a "concrete basis"12 and meet a "recognized threshold ... of [a] reasoned apprehension of harm." ${ }^{\text {13 }}$ A second panel of four justices, led by McLachlin CJC, differed, holding that "[n]o constitutional threshold level of harm ... constrains Parliament's ability to target conduct causing ... evil[]." ${ }^{4}$ Cromwell J, 
who wrote a tie-breaking decision in the case, did not pronounce on the issue, thus leaving the disagreement unresolved.

This paper argues that the "concrete basis and reasoned apprehension of harm" requirement proposed by LeBel and Deschamps JJ in the AHRA Reference provides a sensible and useful demarcation between federal interest in regulating criminal aspects of health, and provincial interests in regulating health as a matter engaged by various heads of provincial powers, and moves us closer to finding a principled solution to federal-provincial disputes over health regulation. ${ }^{15}$

The paper is loosely divided into two sections. The first provides a brief historical overview of the AHRA Reference, and the second explains why the threshold proposed in the case offers a better solution than existing doctrine for the demarcation of federal and provincial legislative authority over health.

\section{The Case}

The Assisted Human Reproduction Act ${ }^{16}$ was enacted in 2004 following almost a decade of deliberative activities provoked by concerns over the health and social implications of technologyassisted procreation and related research. ${ }^{17}$ The original version of the Act was a sweeping piece of criminal legislation that combined outright prohibitions, regulatory controls and diverse administrative mechanisms to govern a broad range of clinical, commercial and research activities related to assisted human reproduction. The Act applied to two broad classes of activities: those prohibited without qualification or exception, ${ }^{18}$ and those allowed if they were carried out in accordance with regulations and a license ("controlled activities"). ${ }^{19}$

In 2007, the Province of Quebec submitted a reference question to the Quebec Court of Appeal in which it contended that the controlled activities, inter alia, were matters subject to provincial exclusive legislative jurisdiction over hospitals, property and civil rights, education and matters of a merely local or private nature, and thus, ultra vires Parliament. The Province conceded that the outright prohibitions in the Act were valid criminal law, but argued that the criminal law power could not be used to justify the regulation of legitimate health care services and the conditions for delivery of such services. $^{20}$

In response to Quebec's challenge, the federal government defended the Act on a number of grounds. The federal government argued that the primary purpose of the legislation was to safeguard public health, safety and morality in relation to assisted reproduction and related research; that the legislative incursion was legitimate since health was a shared subject matter between Parliament and the provinces; that judicial precedent supported the use of the criminal law power to enact a legislative scheme that combined prohibitions and regulatory controls; and that the challenged provisions were integral to and inseparable from the rest of the Act and thus valid under the ancillary powers doctrine. $^{21}$

Ruling in favour of Quebec, the Court of Appeal found that the "fundamental and dominant purpose" of the impugned provisions was "the safeguarding of health and not the elimination of an 'evil'." 22 As such, the provisions could not be characterized as criminal law, and were therefore ultra vires Parliament. The federal government appealed the ruling to the Supreme Court of Canada, which heard arguments on April 24, 2009.

Over a year and half later, an unusually fractured Supreme Court (4-4-1) issued its decision. McLachlin CJC allowed the appeal, ${ }^{23}$ concluding that the impugned provisions were either directed at the legitimate criminal law public purpose of preventing conduct that is "fundamentally immoral, a public health evil [or] a threat to personal security," 24 or were ancillary to this purpose. LeBel and Deschamps JJ disagreed, holding that the impugned provisions were invalidly enacted. ${ }^{25}$ In their opinion, the pith and substance of the impugned provisions was the "regulation of assisted human reproduction as a health service," ${ }^{26}$ a matter that fell squarely under various provincial heads of power including the power to make laws in relation to the establishment, maintenance and 
management of hospitals, property and civil rights, and matters of a merely local nature.

In his brief tie-breaking decision, Cromwell J characterized the dominant purpose of the impugned provisions as the regulation of "virtually all aspects of research and clinical practice in relation to assisted human reproduction." ${ }^{27} \mathrm{He}$ agreed with LeBel and Deschamps JJ that this was a matter within provincial legislative authority, but differed from them by holding that the characterization of purpose did not apply to all of the challenged provisions. ${ }^{28} \mathrm{He}$ then upheld the constitutionally valid provisions ${ }^{29}$ and invalidated the rest. ${ }^{30}$

In June 2012, Parliament repealed the invalidated sections and amended the Act. ${ }^{31}$

\section{The Concrete Basis and Reasoned Apprehension of Harm Threshold}

In their respective decisions, McLachlin CJC and LeBel and Deschamps JJ differed on what qualifies as a valid criminal law public purpose that would support criminal laws directed at health.

In a faithful reading of judicial precedent, McLachlin CJC held that to satisfy this substantive component, Parliament's use of the criminal law power to regulate health must simply "target conduct that constitutes a public health evil." ${ }^{32}$ According to her, this means that Parliament can validly enact provisions aimed at suppressing "conduct that may have an injurious or undesirable effect on the health of members of the public," ${ }^{33}$ regardless of provincial authority to legislate in the field. ${ }^{34}$

LeBel and Deschamps JJ did not dispute this point, but introduced a further requirement. In their opinion, the public health evil Parliament is seeking to suppress "must be real and ... relate to conduct or facts that can be identified and established" 35 and be directed at the "elimination of [a] reasoned risk of harm." 36 The justices reasoned that the main rationale for the proposed requirement is that the Chief Justice's approach reduces the substantive component of criminal law to a formal requirement that is satisfied whenever Parliament invokes a public health concern to enact criminal law provisions that invade provincial legislative space. ${ }^{37}$ They reasoned further that without this proposed requirement:

[F]ederal criminal law power would in reality have no limits. The federal government would have the authority under the Constitution to make laws in respect of any matter, provided that it cited its criminal law power and that it gave part of its legislation the form of a prohibition with criminal sanctions. ${ }^{38}$

There are a number of reasons why this proposed requirement bodes well for federalism disputes concerning health matters. Firstly, the requirement recognizes that health is a complex and amorphous subject that does not fit neatly into the categories available under the constitutional division of powers. To draw a line between health as a provincial matter and health as a criminal law matter, the courts ought to apply a precise characterization that affords equal consideration to both federal and provincial interests rather than an approach that awards priority and paramountcy to Parliament whenever a "public health evil" is present.

By way of contrast, McLachlin CJC's approach simply asks whether Parliament's action addresses a legitimate public health evil. This approach simply does not give any consideration or weight to the provincial story or give the provinces any room in the legislative space shared with Parliament. LeBel and Deschamps JJ point to this concern in rejecting the Chief Justice's finding that a reasonable concern for morality can serve as the basis for the exercise of the criminal law power within this shared space, thus:

The requirement of a concrete basis and a reasoned apprehension of harm applies with equal force where the legislative action is based on morality. In establishing the basis for Parliament's action, the Chief Justice relies heavily on the purpose of upholding public morality. In her view, to justify having recourse to the criminal law by relying on morality, Parliament need only have a reasonable basis to expect that its legislation will address a concern of fundamental importance. If 
her interpretation were adopted, the decision to bring certain conduct within the criminal law sphere would never be open to effective review by the courts. The issue would simply be whether a moral concern is addressed and whether there is a consensus that the concern is of fundamental importance. This approach in effect totally excludes the substantive component that serves to delimit the criminal law. Not only does it go far beyond morality, which as a result serves only as a formal component, but it inevitably encompasses innumerable aspects of very diverse matters of conduct ... which, although they involve moral concerns in respect of which there is a consensus that they are important, cannot all be considered to fall within the criminal law sphere. ${ }^{39}$

Secondly, given that many beneficial health services or practices inevitably have injurious or undesirable effects on health, the Chief Justice's interpretation necessarily implies that virtually every aspect of health is subject to the criminal law power. This is particularly true of assisted reproductive technologies, which are associated with health and other social risks that disproportionately affect women. LeBel and Deschamps JJ emphasize this point in their ruling, in the following way:

\footnotetext{
Medical advances are not limited to the field of assisted human reproduction, and many such advances can raise issues related to ethics, morality, safety and public health. There is no question that the success rate of the first few attempts at heart bypass surgery was less spectacular, the technologies less sophisticated and the materials less diverse. Although heart surgery, like many other medical treatments, may raise issues related to health, safety, ethics and morality, particularly where children, senior citizens or disabled persons are involved, criminalizing the practice of cardiology is not being considered. ${ }^{40}$
}

While it is most certainly not the case that Parliament would seek to criminalize every potentially harmful health-related service or practice, it is still entirely possible for it to act in circumstances where a particular service or practice is largely beneficial or more properly a matter within provincial legislative jurisdiction. Also, in both cases, criminalization may cause more harm than good by creating inflexible rules that do not leave much room for provincial regulation or cooperative national regulation between the federal and provincial governments. LeBel and Deschamps JJ's approach will do a better job at addressing this "dual aspect" problem as it limits the use of the criminal law power in the health context to matters involving real (identifiable) or imminent harms, while allowing for the development of flexible regulatory schemes (national or provincial) that aim to promote the beneficial aspects of health.

Lastly, the "concrete basis" requirement suggests a role for empirical evidence in assessing the constitutionality of the valid criminal law public purpose cited in support of criminal law provisions. As LeBel and Deschamps JJ observe, "risks to health can often be established through empirical studies." ${ }^{41}$ Where the evidence shows that health-related conduct or activity merely presents intangible or potential risks (or is merely repugnant to some), it seems heavy-handed to subject such activity to a prohibitory regulatory regime. More importantly, the need to establish evidence in support of recourse to criminal law might force the federal government to explore other regulatory options such as cooperation with the provinces to develop national standards.

In conclusion, it is regrettable that Cromwell J did not address or resolve the proposed "elimination of [a] reasoned risk of harm" threshold presented by LeBel and Deschamps JJ in the AHRA Reference. However, the fact that several members of the Court were clearly uncomfortable with the characterization of the substantive component of the criminal law power in that case suggests that it will not be long before the matter resurfaces at the Supreme Court.

\section{Notes}

* Assistant Professor and Katz Research Fellow, Faculty of Law, University of Alberta.

1 Constitution Act, 1867 (UK) 30 \& 31 Vict, c 3, reprinted in RSC 1985, App II, No 5.

2 Schneider $v$ The Queen, [1982] 2 SCR 112 at 142; Peter Hogg, Constitutional Law of Canada, 5th ed, loose-leaf (consulted on 30 January 2013), (Toronto: Thomson Reuters, 2007), ch 32 at 1.

3 Hogg, ibid. 
$4 \quad$ Ibid, ch 32 at 1-3; Marlisa Tiedemann, "The Federal Role in Health and Health Care" Library of Parliament, Publication No. 2008-58-E.

5 See generally Hogg, supra note 2, ch 32 at 1-8; See also Ubaka Ogbogu, "Reference re Assisted Human Reproduction Act and the Future of Technology-Assisted Reproduction and Embryo Research in Canada” (2011) 19 Health LJ 153.

6 Reference Re Assisted Human Reproduction Act, 2010 SCC 61, [2010] 3 SCR 457 [AHRA Reference cited to SCC].

7 Reference Re Validity of s 5(a) of the Dairy Industry Act, [1949] SCR 1, aff'd [1950] 4 DLR 689, [1951] AC 179.

8 AHRA Reference, supra note 6 at para 43.

$9 \quad$ Ibid at paras 233-4.

10 Ibid at para 56; RJR MacDonald Inc $v$ Canada (Attorney General), [1995] 3 SCR 199 at para 32, LaForest J.

11 AHRA Reference, ibid.

$12 \quad$ Ibid at para 238.

13 Ibid at 236.

14 Ibid at para 56. She adds that criminal law could target "severest risks to individual health and safety" as well as "less severe harms that are of public concern." Ibid.

15 For fuller treatments of the case, see Graeme G Mitchell, "Not a General Regulatory PowerA Comment on Reference re Assisted Human Reproduction Act" (2011) 54(2) Sup Ct L Rev 633 at 660; Barbara von Tigerstrom, "Federal Health Legislation and the Assisted Human Reproduction Act Reference" (2011) 74:1 Sask L Rev 33; Ogbogu, supra note 5.

16 SC 2004, c 2 [AHRA].

17 For a detailed history of the Act, see Françoise Baylis \& Matthew Herder, "Policy Design for Human Embryo Research in Canada: A History (Part 1 of 2)" (2009) 6:1 Bioethical Inquiry 109.

18 AHRA, supra note 16, ss 5-9. Prohibited activities include the creation of human chimera embryos and human clones, in vitro creation of human embryos for non-reproductive use, creation of hybrids for reproductive use, reproductive uses of hybrids, human chimera embryos, non-human gametes, cells, embryos, fetuses and cells extracted from human embryos or fetuses, developing an embryo outside the human body beyond fourteen days after fertilization or creation, performing sex selection procedures on an embryo intended for reproductive use, germline genetic alteration, use of human reproductive material for embryo creation without donor consent, obtaining gametes from a minor for a purpose other than future procreative use by the donor, surrogacy contracts and associated dealings, and trading of human gametes, embryos, and genes and cells intended for reproductive use (including advertising).

19 Ibid, ss 10-13. Activities in this category include the use of human embryos for reproductive purposes and for improving or providing instruction in assisted reproduction procedures, keeping and handling of gametes and embryos, transgenics (combining genes from different species), reimbursement of expenditures incurred by surrogates, gamete donation, embryo "maintenance and storage" services, and undertaking a controlled activity in unlicensed premises. Quebec (AG) v Canada (AG), 2008 QCCA 1167, 298 DLR (4th) 712 at paras 25-34 [Quebec cited to DLR].

21 Ibid at paras 35-44. For more on the ancilliary powers doctrine see General Motors of Canada Ltd. v City National Leasing, [1989] 1 SCR 641.

22 Quebec, ibid at para 138.

23 Binnie, Fish and Charron JJ concurring.

24 AHRA Reference, supra note 6 at para 88.

25 Abella and Rothstein JJ concurring.

26 Ibid at para 227.

27 Ibid at para 285.

28 Ibid at para 288.

29 Ibid at paras 288-93. Provisions upheld by Cromwell J include sections 8, 9 and 12, which prohibit, respectively, the use of reproductive material for embryo creation without donor consent, obtaining gametes from a minor for a purpose other than future procreative use by the donor, and reimbursement of expenditures arising from surrogacy, gamete donation, and embryo "maintenance and storage" services contrary to regulations. He also upheld section of the Act dealing with mechanisms for implementing these provisions. Ibid at paras 292-293.

$30 \quad$ Ibid at para 294.

31 Jobs, Growth and Long-term Prosperity Act, SC 2012, c 19, s 713. AHRA Reference, supra note 6 at para 57.
Ibid.

Ibid.

Ibid at para 236.

Ibid at para 243.

Ibid at para 238.

Ibid at para 240.

Ibid at para 238 [references omitted].

Ibid at para 255.

Ibid at 241. 